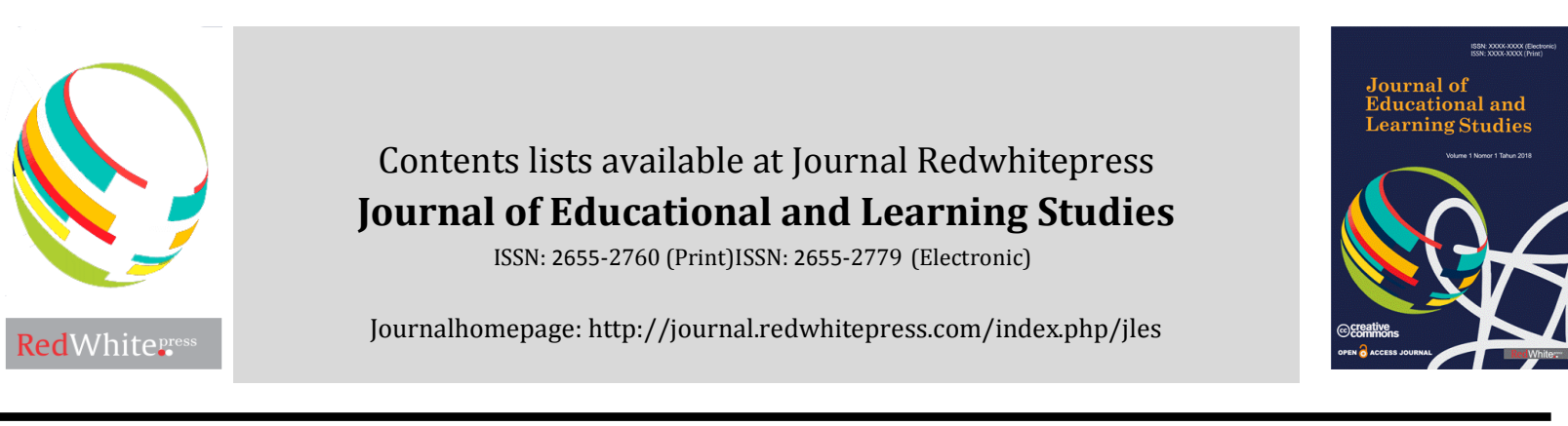

\title{
Improving school climate for better quality educational management
}

\author{
Syahril $^{1}$, Hadiyanto $^{2}$ \\ ${ }^{12}$ Universitas Negeri Padang
}

\begin{tabular}{l} 
Article Info \\
\hline Article history: \\
Received Oct $29^{\text {th }}, 2018$ \\
Revised Nov $16^{\text {th }}, 2018$ \\
Accepted Nov $21^{\text {th }}, 2018$ \\
\end{tabular}

\section{Keyword:}

School Climate

Learning Achievement

Job Satisfaction Special

Education

Work Motivation

Teacher Morale

Teacher Creativity

Work Performance

Teacher Discipline

\begin{abstract}
School climate is a situation formed by a relationship between the principal and teachers, teachers and teachers, teachers and staffs, teachers and students or relationships among students that characterizes a school and distinguishes a school from others. School climate might influence and determine the success of teaching and learning process at schools. The school climate consists of at least four dimensions, namely dimension of relationship, personal growth/development, system maintenance and change, and dimension of physical environment. Based on the studies done in several countries, school climate can be a variable influencing other variables, such as learning achievement, behavior and teacher job satisfaction, teacher work motivation, teacher morale, teacher creativity, teacher work performance, and teacher discipline. So, when the school principal wants to improve those practices, he or she has to make better school climate through common stages namely preliminary assessment, feedback, reflection and discussion, intervention, and finally reassessment.
\end{abstract}

(C) 2018 The Authors. Published by Redwhitepress.

This is an open access article under the CC BY-NC-SA license

(https://creativecommons.org/licenses/by-nc-sa/4.0/

\section{Corresponding Author:}

Syahril,

Universitas Negeri Padang

Email: syahril_fip@yahoo.com

\section{Introduction}

School climate is one of the important factors that determine the success or failure of educational management. A good or conducive school climate can provide support or encouragement to the school principals, teachers, staffs and students to perform various activities according to their respective duties and functions. Hoy and Miskell argue that climate is the quality of the environment (physical and non physical) that is perceived and experienced continuously by every personal organization that directly determine and influence the behavior of various daily activities (Hoy \& Miskell, 1988). It is also argued that the term 'climate' in an organization is like as the personality in humans that directly affect behavior in various activities (Hoy \& Miskell, 1988). The school climate is one of the factors that distinguishes an organization from others. When the analogy is applied to schools, the school climate is the personality of a school that directly affects the behavior of individuals in the school (principals, teachers, staffs and students), and at the same time as a factor differentiating between a school and another school. The above analogy is reasonable because every educational institution or school has certain characteristics that may 
not be the same as other school features, although the physical completeness of facilities and infrastructure, the shape and architecture of the school are the same as other schools. This is because the characteristics of a school is determined by the climate of the school.

In line with that, Sikula argued that the school climate is an extension of the concept of work moral. It associated with the attitude of individuals or groups in carrying out an activity or work in an organization. The school climate includes applications or practices, traditions and work habits within the organization (Pidarta, 1995). Furthermore, the school climate is a set of attributes that give the color or atmosphere of every school. School climate can be traced and viewed based on factors that exist in the school environment, such as curriculum, facilities and infrastructure, principal leadership, patterns of interpersonnel relationships in schools and learning environments in schools (Daryanto \& Tarno, 2015).

Furthermore, school climate refers to shared beliefs, values, and attitudes that accommodate the interaction between students, teachers, employees and administrators (principals) in schools. It manages behavioral parameters that are shown in the values and norms that exist in the school. The school climate also refers to organizational order, good working habits in accordance with applicable regulations. School climate is a product of social interaction between teachers, students, employees, and administrators (principals) who are influenced by education and social values that exist in schools (Bradshaw, Wasdorp, Debnam, \& Johnson, 2014). Therefore, Chand mentions that there are nine factors that contribute functionally to shaping school climate, such as parents, teachers, students, principals, Head of District/Municipal Education Office (Superintendents), Board of Education, staffs at the central office, community in which the school is located, and non-teaching staffs (Chand, 1991).

Based on some points of view of the school climate mentioned above, it can be formulated that the school climate is a situation or atmosphere perceived by the personal school, caused by the relationship or interaction between the principal and teachers, teachers and teachers, teachers and students or relationships among students of a school that differentiates a school from others and influences the success of the learning process in school.

\section{Discussion}

School climate is a situation or atmosphere felt by the school's personal. In order the school climate can be created and nurtured well, it is necessary to develop dimensions that shape the school climate itself. There are three main dimensions that can be used to measure the climate that occurs in a school or organization (Moos, 1979). The three dimensions proposed by Moos are the dimensions of relationship, personal growth, and system maintenance and change formed in an organization. After looking at the dimensions proposed by Moos above, Arter concluded that these dimensions do not include all aspects associated with organizational development. Therefore he added it with dimension of physical environment surrounding the organization (Arter, 1989).

Some experts have designed inventories used to measure the perceived climate in a school. They formulate it in different forms of scale. For example, in the School-Level Environment Questionnaire (SLEQ), there are eight scales used in measuring climate, but there are only two of them that are be used in the Work Environment Scale (WES). Based on those inventories, there are over 35 scales that can be used to measure the school climate in their studies. The scales are in various school climate inventories, such as the School-Level Environment Questionnaire (SLEQ), Work Environment Scale (WES), the Organizational Climate Description Questionnaire (OCDQ), the Organizational Climate Index (OCI), and the High School Characteristics Index (HSCI). However, in general, some experts who examine the school climate still refers to the basic dimensions proposed by Moos (Moos, 1979). There is an Indonesian version of school climate instrument that has been developed and validated (Hadiyanto \& Syahril, 2000), and was used (Sutjipto \& Hadiyanto, 2003). As the results of the development and validation still show weaknesses, and the contemporary context has changed, it is needed to refine and re-validate to teachers of Junior Secondary Schools in some districts and cities in West Sumatra (Syahril, Hadiyanto, Adi, \& Irsyad, 2017).

\section{Relationship between School Climate and Other Variables}

School climate is one factor that is very influential on teachers' behavior and performance in a school. In line with that, there are some documents showing the relationship between school climate and various other variables that exist around the school (Hadiyanto, 2016). 
1. School Climate and Student Achievement

Student achievement is influenced by many factors, namely internal and external factors such as ability, interest, learning style of learners, teachers, facilities available, and no less important is the school climate. Moos argues that a conducive social climate in schools has a great influence on the learning satisfaction and personal growth of learners (Walberg, 1979). The opinion is very rational because a conducive school climate will in turn affect student achievement. In addition, Walberg in Farley (Lewin, 1935) and (Farley \& Gordon, 1981) and Sweetland and Hoy (Daryanto \& Tarno, 2015) also suggested a relationship between school climate and learning achievement of students. Conducive classroom climate will encourage students to learn well in school and in turn will clearly improve their achievement and learning outcomes. It is also suggested that climate and learning environment have a considerable influence on the success of students in the school. A conducive climate and environment will provide a sense of security, comfort and freedom both for teachers, employees and for learners to perform activities in accordance with their respective functions. This is what enables teachers, employees and learners to improve the performance of their study and work (Pidarta, 1995).

\section{School Climate and Teacher's Behavior and Job Satisfaction}

The linkage between the work environment or organizational climate to the behavior of existing personnel within the organization has actually begun to be studied since tens years ago, which suggests that individual behavior is the result of the interrelationships between individuals and their work environment. To know and predict the psychological behavior of individuals in the organization ones must understand the various psychological events in the organization such as actions, emotions and expression of a person (personality) and psychological environment (Lewin, 1935). In line with that Murray suggests that the behavior of a person in the organization is influenced by internal and external factors such as personality and organizational climate (Fisher, 1990). Furthermore, it is also argued that a conducive school climate contributes substantially to the improvement of the quality of school personnel (teachers, students and staffs) behaviors in their activities in accordance with their respective functions and duties (Hyman, 1980).

The above opinion is also supported by the results of several studies showing that the work environment is very influential on employee behavior in the organization. The research showed that the school climate affects the satisfaction of elementary school teachers (Mufidayati, 1998). In addition, the school climate has an influence on teacher's job satisfaction of 35.6\% (Baedhowi, 1998). While other research shows that there is a positive and significant correlation between school climate and teacher work performance in senior high school in East Jakarta, school climate contributes to teacher work performance of $13.7 \%$ (Syafri, 2004).

\section{School Climate and Teacher's Work Motivation}

School climate is an environmental factor that influences teacher's work motivation. Some studies showed that organizational (school) climate significantly influenced employee's work motivation in performing the task (Rahmawati, 2015), influenced teacher's work motivation in elementary school. In addition, every improvement of school organizational climate by $1 \%$, then teacher work motivation will increase by $58 \%$ (Sucianti, 2015). It is also found that organizational climate has an effect on teacher's motivation, achievement and job satisfaction (Mangkunegara, 2015). Teachers want a pleasant working climate in performing the task, as this will encourage them to work better. Conversely, a bad organizational climate will directly affect teacher motivation and performance (Bishay, 1996).

\section{School Climate and Teacher's Spirit}

The spirit of work is one's attitude and willingness to carry out the work to which it is responsible (Hasley, 2001). Someone who has a good morale can be ascertained that the person will always carry out the tasks and responsibility well, so that will get maximum results. One way that can be done to improve the morale of teachers is to improve the school climate. This is supported by the results of research showing that the school climate has a positive and significant relationship (meaning) with the spirit of teacher work (Sari, 2016). Some other researchers also claimed that there was a positive influence between school climate on teacher work spirit (Triyanah \& Suryadi, 2016), (Sinay, 2017).

\section{School Climate and Teacher's Creativity}


One's creativity arises not only because of its intrinsic drive, but because of the environmental climate that enables it to feel secure to work, to imagine and to take initiative so that there is the courage to take risks. Baran and Zan stated that there was strong influence of the organizational environment in encouraging employee creativity (Dale, 1992). Furthermore, Dale stated that creativity needs to be sustained by the organizational climate (Dale, 1992). The importance of organizational climate influence was also proved by other researcher which stated that school climate had positive and significant effect on creativity of science teacher 48,9 (Teguh, 2007). The research conducted by McAlindon concluded that everyone is born creative, but this creative power is somewhat disappear in the process of maturity. To keep this natural creativity alive and productive, organizational conditions and climates should be created to enable teachers to be free to develop (Dale, 1992).

6. School Climate and Teacher's Performance

Performance of teachers is an achievement of work resulted from the work ability of a teacher in accordance with the competence, duties and responsibilities, good moral, and positive behavior, so that it can affect the efforts to improve the quality of education. Teacher performance may be influenced by the school environment or climate in which they are assigned. This is supported by some researchers, such as (Yulia, 2016) and (Fitriana, 2013) showing that there is a significant relationship between school climate and teacher performance. In addition, some studies conducted by (Irfan, 2007), (Suharto, 2009) and (Lidyawati, 2014) also found a positive and significant relationship between school climate and teacher performance. This means the better the school climate, the better performance of teachers in school. Only a few researcher such as (Raghavan, 1998) stating that organizational climate has a simple positive association with work performance. So in general, it can be concluded that the school climate also affects teachers' work performance.

7. School Climate and Teacher's Disciplin

A good and harmonious school climate is needed by all educators and educational staffs in schools to perform their roles and functions well. In addition, a conducive school climate helps to create an effective school (Supardi, 2013), and contributes to teacher discipline with a contribution of 14.2\% (Rahmi, 2016).

\section{School Climate Improvement Steps}

School climate can be improved better in accordance with the desired teacher. When the school climate is matched by what the teacher wants, they can work better, so that in turn it can improve the teacher's performance (person-environment-fit). In conducting school climate, there are five steps to create the desired school climate as a standard for improvement. The five steps are: 1) assessment, 2) feedback, 3) reflection and discussion, 4) intervention, and 5) reassessment (Fisher \& Fraser, 1982).

1. Assessment

Assessment was conducted by disseminating two kinds of school climate inventories, the actual and preferred forms to the teachers. Actual form is distributed first, then followed by preferred form. This can also be done by distributing the actual form to half teachers and preferred form to some other teachers at the same time. With this initial assessment, there will be known whether or not there is a difference between actual school climate with its preferred.

2. Feedback

After data collection and analysis, the researcher gives information to the teachers and school principal the result of actual and preferred form data analysis. At this stage the teachers and principal will know whether or not there is a significant difference in each school climate scale. If there are differences, and perhaps differences on a certain scales are very significant, the teachers and principal needs to think about changes to increase the scale of the actual school climate to fit the scale preferred by teachers.

\section{Reflection and Discussion}

Reflections and discussions were conducted both by teachers and principals, formally and informally on the need to improve school climate. Teachers and/or principals may choose certain scales that need to be prioritized for improvement. For example, on the scale of 'innovation' there is a significant difference between actual and preferred climate, teachers and/or principals can decide to improve 'innovation' scale in schools. 
4. Intervention

After the principal chooses to make better innovation in school, the principal can provide the teacher with ideas of renewal and ways of execution. The principals can also reward teachers whose innovative ideas are accepted and implemented in schools. Teachers are encouraged to more actively read the source book or find other ways in finding innovative ideas for improving the school climate.

The intervention process can be implemented two, three months, or even one to two years depending on the needs. The more complex and the scale to be increased, the longer it will take.

5. Reassessment

After the principal feels that the process of intervention is sufficient, the principal reassessed by readministering the actual form (post test) of inventory. The results of this reassessment are then compared with the results of the initial assessment (pre test). If there is a significant difference between the results of the two measures, then the corrective intervention step can be declared successful. On the contrary, if there has been no significant improvement, the principal may repeat the intervention process so that the principal believes there is a significant increase on the scale to be improved.

\section{Conclussion}

Based on the above discussion then there are some conclusions as follows:

1. School climate is a situation or atmosphere caused by a relationship or interaction between the principal and teachers, teachers and teachers, teachers and staffs, teachers and students, or relationships among students who characterize a school that distinguishes a school from others. The school climate is believed influence and determine the success of teaching and learning process in school.

2. School climate can be seen from four dimensions, namely dimension of 1) relationship, 2) personal growth, 3) system maintenance and change, and 4) physical environment. These four dimensions can be broken down into more complex scales.

3. School climate is one of the variables that have been often associated with other variables in several studies, as with the variables of student achievement, teacher behavior, job satisfaction of teachers, teacher work motivation, teacher work spirit, teacher creativity, teacher work performance, and teacher discipline.

4. To improve school climate for better educational management, there are at least five stages proposed by experts. They are 1) preliminary assessment, 2) feedback, 3) reflection and discussion, 4) intervention, and 5) reassessment. Teachers and school principals can do collaborative school climate improvement through school action research implementing those stages.

\section{Acknowledgments}

Although the study of school climate has grown rapidly in developed countries, this study has not been massively conducted by researchers or educational observers in Indonesia. Therefore, we express our deepest gratitude and appreciation to the researchers who have pursued this study and have published it so that the results of his research can be known by many parties. Hopefully with more studies on school climate, the learning process in schools in Indonesia will become better.

\section{References}

Arter, J. A. (1989). Assessing school climate and classroom climate. Portland, Oregon: Test Centre of the Northwest Regional Educational Laboratory.

Baedhowi. (1998). Iklim Organisasi, Kepuasan Kerja dan Kinerja Sekolah Menengah Umum se Jabotabek. In Thesis. Jakarta: Universitas Indonesia.

Bishay, A. (1996). Teacher Motivation and Job Satisfaction: A StudyEmploying the Experience Sampling Method. Journal of UndergraduateSciences, 3, 147-154. 
Bradshaw, C. P., Wasdorp, T. E., Debnam, K. J., \& Johnson, S. L. (2014). Measuring school climate in high schools: a focus on safety, engagement, and the environment. Journal of School Health, 84(9).

Chand, K. (1991). Excellence in American education through improving school climate. New York: United States Department of Education.

Dale, T. (1992). Kinerja. Jakarta: PT. Gramedia.

Daryanto, \& Tarno. (2015). Pengelolaan Budaya dan Iklim Sekolah. Jakarta: Gava Media.

Farley, F. H., \& Gordon, N. J. (1981). Psychology and Education: The State of the Union. Berkeley, California: McCutchan Publishing Corporation.

Fisher, D. L. (1990). The Assessment and Change of Classroom and School Environment. Launceston.

Fisher, D. L., \& Fraser, B. J. (1982). Use of classroom environment scale in investigating relationship between achievement and environment. Journal of Science and Mathematics Education in South East Asia, 5(2), 5-9.

Fitriana, D. N. I. (2013). Pengaruh Iklim Sekolah dan Kepuasan Kerja Terhadap Kinerja Guru SD di Kecamatan Muntilan Kabupaten Magelang. Skripsi. Yokyakarta: Universitas Negeri Yokyakarta.

Hadiyanto. (2016). Teori dan pengembangan iklim kelas dan iklim sekolah. Jakarta: Kencana.

Hadiyanto, \& Syahril. (2000). Pengembangan dan validasi alat ukur iklim sekolah. Padang.

Hasley. (2001). Pendekatan Manusiawi dan Organisasi Terhadap Pembinaan Kepegawaian. Jakarta: Gunung Agung.

Hoy, W. K., \& Miskell, C. G. (1988). Educational Administration: Theory, Research and Practice. New York: Random House.

Hyman, R. T. (1980). School administrator's handbook of teacher supervision and evaluation methods. New Jersey: Prentice Hall, Englewood Cliffs.

Irfan. (2007). Pengaruh Pelaksanaan Supervisi Kunjungan Kelas Oleh Kepala Sekolah dan Iklim Sekolah Terhadap Kinerja Guru di Empat SMP Negeri Sub MKKS Taman Kabupaten Pemalang. In Thesis. Pasca Sarjana Universitas Negeri Semarang.

Lewin, K. (1935). A Dynamic Theory of Personality. New York: McGraw-Hill Book Company.

Lidyawati, N. K. A. (2014). Pengaruh Pengembangan Profesi, Iklim Sekolah, dan Kepemimpinan kepala sekolah terhadap kinerja guru di SMA Negeri 1 Abiansemal Tahun 2013, 4.

Mangkunegara, A. . (2015). Manajemen Sumber Daya Manusia Perusahaan. Bandung: PT Remaja Rosdakarya.

Moos, R. H. (1979). Evaluating educational environments. Washington: Jossey-Bass Publishers.

Mufidayati, K. (1998). Analisis Hubungan Iklim Organisasi dan Motivasi dengan Kepuasan Kerja Tenaga Kependidikan pada Sekolah Dasar Islam Terpadu Nurul Fikri. In Thesis. Jakarta: Universitas Indonesia.

Pidarta, M. (1995). Peranan Kepala Sekolah pada Pendidikan Dasar. Jakarta: PT Gramedia.

Raghavan, P. A. (1998). Iklim Organisasi Dan Perkaitannya Dengan Prestasi Kerja Guru Sekolah Menengah Di Ampang. In Tesis. Universiti Putra Malasya.

Rahmawati, R. (2015). Pengaruh iklim organisasi terhadap motivasi kerja pegawai di kantor wilayah Kementerian Agama Provinsi Sumatera Barat. Universitas Negeri Padang.

Rahmi, A. (2016). Kontribusi Supervisi Kepala Sekolah dan Iklim Sekolah Terhadap Disiplin Kerja Guru MTSN Kota Padang. Tesis.

Sari, D. P. (2016). Hubungan Iklim Sekolah dengan Semangat Kerja Guru SMK Swasta Se-Kota Padang Panjang. Skripsi.

Sinay, S. N. (2017). Kepemimpinan Visioner, Iklim Sekolah, Continuing Professional Development Dan Kepuasan Kerja Guru SMP. Jurnal Administrasi Pendidikan, XXIV(1).

Sucianti, S. (2015). Pengaruh iklim organisasi sekolah terhadap motivasi kerja guru di Sekolah Dasar Negeri Dabin 
Improving school climate for better quality educational management

I dan II Kecamatan Kuwarasan Kabupaten Kebumen. Universitas Negeri Semarang.

Suharto. (2009). Hubungan Antara Iklim Organisasi dan Kreativitas Guru Dengan Kinerja guru Di SMA Negeri Kota Bengkulu. Jurnal Ilmiah Manajemen Pendidikan, 3(5).

Supardi. (2013). Kinerja guru. Jakarta: Raja Grafindo.

Sutjipto, \& Hadiyanto. (2003). Upaya kepala sekolah dalam menciptakan iklim sekolah dasar di Jakarta. Jakarta.

Syafri, D. (2004). Hubungan antara Iklim Sekolah dengan Prestasi Kerja Guru Sekolah Menengah Umum Negeri di Jakarta Timur. Forum Pendidikan, 29(2).

Syahril, Hadiyanto, Adi, N., \& Irsyad. (2017). Pengembangan dan Pemvalidasian Alat Ukur serta Perbaikan Iklim Sekolah Menengah Pertama di Sumatera Barat. Padang.

Teguh, A. (2007). Pengaruh kepemimpinan kepala sekolah Dan iklim organisasi Terhadap kreativitas guru IPA SMPNegeri Se kotaPekalongan. Tesis. Universitas Negeri Semarang.

Triyanah, T., \& Suryadi, E. (2016). Iklim Sekolah sebagai Determinan Semangat Kerja Guru Sekolah Menengah Kejuruan. Jurnal Pendidikan Manajemen Perkantoran, 1(1), 75-83.

Walberg, H. J. (1979). Educational environments and effects, evaluation, policy and productivity. Berkeley, California: McCutchan Publishing Corporation.

Yulia, F. (2016). Pengaruh Iklim Sekolah Dengan Kinerja Guru Di Sekolah Menengah atas Negeri SeKecamatan Sungai Tarab Kabupaten Tanah Datar. Skripsi. 